\title{
STUDI PEMBUATAN MARSHMALLOW DENGAN VARIASI KONSENTRASI GELATIN DAN SUKROSA
}

\author{
Krisnasari Arizona ${ }^{1}$, Dyah Titin Laswati, Kuntjahjawati SAR.
}

\begin{abstract}
A study of "Study of Making Marshmallows with Various Concentrations of Gelatin and Sucrose" The purpose of this study was to study the appropriate ratio of gelatin and sucrose to make marshmallows so that they get a chewy marshmallow texture. This research was conducted using a completely randomized design (CRD). Making marshmallows with a ratio of gelatin 1: sucrose 1, gelatin 1: sucrose 4, gelatin 1: sucrose 6, gelatin 1: sucrose 8 and gelatin 1: sucrose 12. Chemical tests were carried out: moisture content, ash content, total sugar content, sugar content reduction. Physical test and organoleptic test: color, texture and preferences. To find out the real difference in treatment, it was continued with Duncan's Multiple Range Test (DMRT) analysis with a significance level of 0.05. Based on the results of the study, it can be concluded that marshmallow making produced different textures for each, but the best results were obtained in the ratio of gelatin 1: sucrose 1 which had a water content of $42.22 \%$, an ash content of 2.86 (\% $\mathrm{db}$ ), and a total sugar content ( $\% \mathrm{db})$, reducing sugar level $16.87(\% \mathrm{db})$, texture $1.588 \mathrm{~N}$, scoring test which has a color score of 4.133 which means slightly yellowish white and texture which has a score of 3.76 .
\end{abstract}

Keyword: marshmallow, gelatin, sucrose

\begin{abstract}
ABSTRAK
Telah dilakukan studi tentang "Studi Pembuatan Marshmallow dengan Variasi Konsentrasi Gelatin dan Sukrosa" Tujuan penelitian ini mempelajari perbandingan gelatin dan sukrosa yang tepat untuk membuat marshmallow sehingga mendapatkan tekstur marshmallow yang kenyal. Penelitian ini dilaksanakan dengan menggunakan Rancangan Acak Lengkap (RAL). Pembuatan marshmallow dengan perbandingan gelatin $1:$ sukrosa 1, gelatin $1:$ sukrosa 4, gelatin 1 : sukrosa 6, gelatin 1 : sukrosa 8 dan gelatin 1 : sukrosa 12. Dilakukan uji kimia : kadar air, kadar abu, kadar gula total, kadar gula reduksi. Uji fisik dan uji organoleptik : warna, tekstur dan kesukaan. Untuk mengetahui beda nyata pada perlakuan dilanjutkan dengan analisa Duncan's Multiple Range Test (DMRT) dengan taraf signifikansi $0,05$. Berdasarkan hasil studi dapat disimpulkan pembuatan marshmallow yang dilakukan menghasilkan masing-masing tekstur yang berbeda namun hasil terbaik diperoleh pada perbandingan gelatin 1 : sukrosa 1 yang memiliki kadar air 42,22\%, kadar abu 2,86 (\% db), kadar gula total (\% db), kadar gula reduksi 16,87 (\% db), tekstur 1,588 N, uji scoring yang memiliki skor warna 4,133 yang berarti putih agak kekuningan dan tekstur yang memiliki skor 3,76.
\end{abstract}

Kata kunci: marshmallow, gelatin, sukrosa

\section{PENDAHULUAN}

Marshmallow adalah foam yang mengandung gula teraerasi, yang distabilkan dengan gelatin dan albumen telur. Marshmallow merupakan makanan ringan sejenis permen yang bertekstur seperti busa yang lembut, ringan, kenyal dalam berbagai bentuk, aroma, rasa dan warna sehingga tergolong dalam produk confectionery, marshmallow termasuk dalam produk permen lunak bukan jelly. Marshmallow bila dimakan meleleh di dalam mulut karena merupakan hasil dari campuran gula atau sirup jagung, putih telur, gelatin dan bahan perasa yang dikocok hingga mengembang (Nakai dan Modler, 1999).

Produk marshmallow umumnya berbahan dasar sukrosa dan sirup glukosa. Gula (sukrosa) dalam pembuatan permen berfungsi sebagai pemberi rasa manis, penentu tekstur permen, dan penentu kenampakan permen karena berpengaruh terhadap warna melalui karamelisasi. Sukrosa dapat meningkatkan titik didih larutan dan larut dalam air. Sukrosa juga berperan sebagai pengawet karena dapat mengurangi aktivitas air 
(Aw) dan menyebabkan plasmolisis sel pada bakteri. Sirup glukosa berfungsi sebagai pengawet, pencegah kristalisasi gula, pemberi tekstur halus, dan pencegah produk pangan mengalami kebusukan (Future Today, 2009 dalam Tanalo 2014).

Gula sangat berpengaruh terhadap pembuatan soft candy, gula (Sukrosa dan glukosa) pada pembuatan soft candy yaitu untuk meningkatkan intensitas rasa manis, menurut Lestariani (2008), glukosa memberikan tekstur yang plastis dan dapat mencegah terbentuknya kristal gula, sedangkan menurut Nadriyanti (2005), jumlah sukrosa yang lebih banyak akan mengalami kekerasan (pengkristalan gula bagian luar) yang mengakibatkan peningkatan kekerasan pada soft candy. Sirup glukosa dapat mengendalikan tingkat kekerasan pada soft candy. Sirup glukosa memiliki sifat sulit untuk mengkristal dan dapat menghindari produk dari tekstur keras. Pemakaian sirup glukosa dicampur dengan sukrosa secara bersamaan dapat meningkatkan rasa manis bila dibandingkan dengan penggunaan salah satu komponen sendiri (Tjokoadikoesoemo, 1993). Jumlah sukrosa dan sirup glukosa yang digunakan dalam pembuatan soft candy perlu disesuaikan, karena kesalahan rasio kedua bahan tersebut dapat menyebabkan penyimpangan produk, maka ketepatan formula dan pengontrolan proses sangat penting (Wahyuni, 1998).

Pada studi ini adalah untuk mengetahui pengaruh konsentrasi gula sukrosa dengan gelling agent dalam terbentuknya marshmallow. Sehingga diperlukan pemilihan konsentrasi gelling agent yang tepat untuk membentuk tekstur marshmallow yang kenyal dan ringan. Gelling agent merupakan bahan tambahan pangan yang digunakan untuk mengentalkan dan menstabilkan serta memberikan tekstur makanan melalui pembentukan gel. Jenis-jenis bahan pembentuk gel biasanya merupakan bahan berbasis polisakarida atau protein. Contoh-contoh dari bahan pembentuk gel antara lain asam alginat, sodium alginat, kalium alginat, kalsium alginat, agar, karagenan, locust bean gum, pektin dan gelatin, namun pada umumnya yang digunakan sebagai bahan dasar dalam pembuatan marshmallow adalah gelatin (Alikonis, 1979 dalam Jariyah dkk., 2019). Gelatin merupakan hidrokoloid yang mempunyai sifat dapat berubah secara reversible dari bentuk sol menjadi gel, yaitu meleleh jika dipanaskan dan membentuk gel kembali jika didinginkan (Herawati, 2008). Sol merupakan jenis koloid di mana fase terdispersinya berupa zat padat, sedangkan medium pendispersinya berupa zat cair atau zat padat. Jika medium pendispersinya zat padat, disebut sol padat sedangkan Gel merupakan jenis koloid yang terbentuk dari campuran zat padat dan zat cair. Gel terbentuk karena fase terdispersi mampu mengadsorbsi medium pendipersinya. Sehingga fase Sol pada gelatin terjadi apabila lingkungan kekurangan air atau hipotonik, sedangkan fase gel terjadi ketika lingkungan kelebihan air atau hipertonik (Santoso, 2015). Gelatin merupakan senyawa turunan protein yang mengandung 18 asam amino. Gelatin pada marshmallow merupakan bahan dasar yang berfungsi untuk meningkatkan tekstur dan chewing ability (Meiners et al., 1984 dalam Jariyah dkk., 2019).

\section{BAHAN DAN METODE Bahan}

Bahan-bahan yang digunakan dalam pembuatan marshmallow adalah gelatin halal terbuat dari tulang sapi yang di dapat dari toko Tekun Jaya, sukrosa merk Gulaku, sirup glukosa yang di dapat dari toko intisari, tepung jagung, tepung gula dan air. Bahan-bahan kimia untuk analisa adalah $\mathrm{CuSO}_{4}$, aquades, $\mathrm{Na}_{2} \mathrm{CO}_{3} 10 \%, \mathrm{~Pb}$ Asetat, $\mathrm{KI}, \mathrm{H}_{2} \mathrm{SO}_{4} 26,5 \% \mathrm{~N}, \mathrm{Na}_{2} \mathrm{CO}_{3} 1 \mathrm{~N}$.

Peralatan yang digunakan dalam penelitian ini meliputi alat untuk pembuatan marshmallow, alat untuk analisis karakteristik fisik dan kimia marshmallow. Alat-alat yang digunakan dalam pembuatan marshmallow adalah: wadah baskom, mixer, panci, loyang, timbangan analitik. Alat untuk analisis kimia yaitu labu takar, biuret, statif, botol timbang, erlenmeyer, gelas beker, oven, desikator, penjepit, corong kaca, gelas ukur, pipet volume, tanur pengabuan, cawan porselen. Alat untuk analisis fisik menggunakan mesin UTM (universal Testing Machine) dengan metode tekanan. 


\section{Proses pembuatan marshmallow}

Penambahan gelatin dalam marshmallow berfungsi sebagai pembentuk gel. Pada penelitian ini ditambahkan perbandingan gelatin dan sukrosa sebesar 1:1, 1:4, 1:6, 1:8 dan 1:12 dari berat bahan total yaitu sebanyak $410 \mathrm{~g}$.

Tahapan yang dilakukan adalah sebagai berikut air (84 gram) dan gelatin dipanaskan hingga $70^{\circ} \mathrm{C}$ selama 5 menit, kemudian sukrosa, sirup glukosa (81,2 gram) dan air (84 gram) dipanaskan hingga suhu $112^{\circ} \mathrm{C}$ selama 5 menit.

Tahap selanjutnya adalah proses pencampuran (mixing) larutan gula dan larutan gelatin, kemudian dikocok rata menggunakan mixer selama 10 menit dengan kecepatan tinggi. Setelah proses pengocokan dengan mixer, adonan marshmallow di cetak dalam loyang dengan ukuran $15 \mathrm{~cm} \times 20 \mathrm{~cm} \times 3 \mathrm{~cm}$ yang sudah terpasang kertas roti, kemudian pendiaman selama 16 jam dalam suhu kamar. Setelah 16 jam pendiaman, marshmallow dikeluarkan dari cetakan. Sebelum dilakukan pemotongan, marshmallow dibaluri oleh tepung gula $5 \mathrm{~g}$ dan pati jagung $5 \mathrm{~g}$ agar tidak lengket. Produk di potong dengan ukuran $1,5 \mathrm{~cm}$ x $1,5 \mathrm{~cm} \times 1,5 \mathrm{~cm}$, produk yang telah dipotong kemudian dilakukan pengemasan menggunakan plastik transparan. Produk yang telah dikemas selanjutnya dilakukan analisa kimia, analisa fisik dan uji organoleptik.

\section{Analisa data}

Metode penelitian ini menggunakan Rancangan Acak Lengkap (RAL) dan masingmasing perlakuan diulang sebanyak 3 kali. Data yang diperoleh dianalisa dengan menggunakan analisa ragam (ANOVA) untuk mengetahui adanya perbedaan diantara perlakuan digunakan Uji DMRT dengan taraf 5\%.

\section{HASIL DAN PEMBAHASAN}

Analisa Kimia meliputi kadar air, kadar Abu, kadar sukrosa, kadar reduksi. Analisa ini dilakukan untuk mengetahui kandungan kadar air, kadar abu, kadar sukrosa dan gula reduksi sudah sesuai dengan standar SNI 3547.2:2008. Analisa kimia dapat dilihat pada Tabel 1.

\begin{tabular}{|c|c|c|c|c|}
\hline Perlakuan & $\begin{array}{c}\text { Kadar } \\
\text { Air }(\%)\end{array}$ & $\begin{array}{c}\text { Kadar } \\
\text { Abu } \\
(\% \mathrm{db})\end{array}$ & $\begin{array}{c}\text { Kadar } \\
\text { gula total } \\
(\% \mathrm{db})\end{array}$ & $\begin{array}{c}\text { Kadar gula } \\
\text { reduksi } \\
(\% \mathrm{db})\end{array}$ \\
\hline $\begin{array}{l}\text { Gelatin 1: } \\
\text { Sukrosa 1 }\end{array}$ & $42,22 \mathrm{a}$ & $2,86 \mathrm{a}$ & $48,66 \mathrm{a}$ & 16,87 a \\
\hline $\begin{array}{l}\text { Gelatin 1: } \\
\text { Sukrosa 4 }\end{array}$ & $35,60 \mathrm{~b}$ & $2,05 \mathrm{~b}$ & $55,70 \mathrm{~b}$ & $18,28 \mathrm{~b}$ \\
\hline $\begin{array}{l}\text { Gelatin } 1 \text { : } \\
\text { Sukrosa } 6\end{array}$ & $35,60 \mathrm{bc}$ & $1,83 \mathrm{c}$ & $57,45 \mathrm{c}$ & $21,88 \mathrm{c}$ \\
\hline $\begin{array}{l}\text { Gelatin 1: } \\
\text { Sukrosa } 8\end{array}$ & $34,01 \mathrm{bc}$ & $1,71 \mathrm{c}$ & $56,89 \mathrm{~d}$ & $20,51 \mathrm{~d}$ \\
\hline $\begin{array}{l}\text { Gelatin 1: } \\
\text { Sukrosa } 12\end{array}$ & $28,66 \mathrm{~d}$ & $1,30 \mathrm{~d}$ & $65,91 \mathrm{e}$ & $23,56 \mathrm{e}$ \\
\hline
\end{tabular}

Keterangan: Rerata yang diikuti huruf yang sama dalam satu kolom menandakan antara perlakuan tidak berbeda nyata pada taraf signifikansi 5\%.

\section{Kadar Air}

Kadar air merupakan parameter yang mempunyai peranan yang besar terhadap stabilitas mutu suatu produk. Kadar air dalam bahan pangan ikut menentukan kesegaran dan daya awet bahan pangan tersebut, kadar air yang tinggi atau melebihi standar mengakibatkan mudahnya bakteri, kapang, dan khamir untuk berkembang biak, sehingga akan terjadi perubahan pada bahan pangan (Winarno, 1997). Selain itu kadar air juga sangat berpengaruh terhadap tekstur serta cita rasa produk. Oleh karena itu pada penelitian ini perlu dilakukan analisa kadar air pada produk terbaik berdasarkan uji kimia. Kadar air merupakan banyaknya air yang terkandung dalam bahan yang dinyatakan dalam persen.

Kadar air juga salah satu karakteristik yang sangat penting pada bahan pangan, karena air dapat mempengaruhi penampakan, tekstur, dan citarasa pada bahan pangan. Marshmallow termasuk salah satu produk makanan semi basah, produk ini umumnya mempunyai kadar air sekitar 20-40\% (Minarni 1996).

Berdasarkan hasil analisis sidik ragam menunjukkan bahwa perbandingan gelatin dan sukrosa memberikan pengaruh beda nyata pada taraf signifikansi 5\% terhadap kadar air marshmallow yang dihasilkan namun pada perbandingan Gelatin 1: Sukrosa 4, Gelatin 1 : Sukrosa 6, Gelatin 1 : Sukrosa 8 tidak beda nyata. Pada Tabel 1, kadar air yang paling tinggi di peroleh pada perbandingan Gelatin 1 : Sukrosa 1 
dimana kadar gelatine sebesar 75,4 g dan kadar sukrosa sebesar 75,4 g. Air yang teranalisa pada penetapan kadar air adalah air bebas yang ada dalam bahan. Dalam hal ini termasuk juga air yang terikat secara fisik yaitu air yang terdapat di dalam misel-misel gel gelatin pada marshmallow. Semakin besar jumlah gelatin yang ditambahkan maka akan semakin banyak air yang terikat dalam misel-misel gel gelatin (Fennema 1985 dalam Sartika 2009). Daya ikat air merupakan salah satu karakteristik fungsional dari protein. Daya ikat air adalah kemampuan daging untuk mengikat air yang ada dalam bahan maupun yang ditambahkan selama proses pengolahan, atau kemampuan struktur bahan untuk menahan air bebas dari struktur tiga dimensi protein, ada beberapa faktorfaktor yang mempengaruhi daya ikat air adalah konsentrasi protein, $\mathrm{pH}$, kekuatan ionik, suhu, keberadaan komponen pangan lainnya, lemak, garam, laju dan lama perlakuan panas (Zayas, 1997). Menurut Standar Nasional Indonesia (SNI) 3547.2:2008 memiliki batas maksimal 20\%, kadar air yang mendekati batas maksimal yaitu pada perbandingan Gelatin 1 : Sukrosa 12 dengan kadar sebesar $28,66 \%$.

\section{Kadar Abu}

Sebagian besar bahan makanan, yaitu sekitar 96\% terdiri dari bahan organik dan air. Sisanya terdiri dari unsur mineral. Unsur mineral juga dikenal sebagai zat anorganik atau kadar abu. Dalam proses pembakaran, bahan-bahan organik terbakar tetapi zat anorganik tidak, karena itulah disebut abu (Winarno 1997).

Berdasarkan hasil analisis sidik ragam menunjukkan bahwa perbandingan gelatin dan sukrosa memberikan pengaruh beda nyata pada taraf signifikansi 5\% terhadap kadar abu marshmallow yang dihasilkan, namun pada perbandingan Gelatin 1 : Sukrosa 6 dan Gelatin 1 : Sukrosa 8 tidak terjadi beda nyata. Pada Tabel 8 , kadar abu yang paling tinggi di peroleh pada perbandingan Gelatin 1 : Sukrosa 1 dimana kadar gelatin sebesar 75,4 g dan kadar sukrosa sebesar $75,4 \mathrm{~g}$, kadar abu yang diperoleh yaitu sebesar 2.86\%. Menurut Standar Nasional Indonesia (SNI) 3547.2:2008 memiliki kadar abu sebesar $3 \%$.
Kadar abu yang terdapat pada marshmallow diduga berasal dari gelatin. Pada saat ekstraksi gelatin, keberadaan mineral yang tergolong jenis abu masih ada yang tersisa dan berasosiasi dengan gugus reaktif dari molekul gelatin seperti gugus $\mathrm{OH}, \mathrm{COOH}$ dan $\mathrm{NH}_{2}$. Hal tersebut berarti semakin banyak gelatin yang ditambah maka kadar abunya pun lebih tinggi. Selain itu, bahan tambahan marshmallow seperti tepung gula juga dapat mempengaruhi beragamnya nilai kadar abu marshmallow. Kadar abu marshmallow dengan perbandingan sukrosa dan gelatin memiliki nilai yang memenuhi standar yang telah ditetapkan oleh SNI. Marshmallow dengan perbandingan Gelatin 1 : Sukrosa 12 memiliki kadar abu yang paling baik yaitu dengan kadar 1,3\% karena semakin sedikit kadar abu, semakin baik mutu marshmallow yang dihasilkan. Seluruh perbandingan memenuhi standar, karena kadar abu pada masing-masing perbandingan berada di bawah batas maksimum yang ditetapkan.

\section{Kadar Gula Total}

Pengertian dari kadar gula total adalah kandungan gula keseluruhan dalam suatu bahan pangan monosakarida maupun oligosakarida. Pembuatan marshmallow menggunakan sukrosa sebagai salah satu bahan baku, karena selain dapat memberi rasa manis juga memberikan peranan dalam pembentukan gel permen. Sukrosa dapat dikombinasikan dengan monosakarida seperti glukosa atau fruktosa, untuk mencegah kristalisasi (Birch dan Parker 1979). Campuran glukosa atau fruktosa dengan sukrosa akan menghasilkan tekstur yang lebih liat tetapi sifat kekerasan permen cenderung menurun (Ward 1977 dalam Sartika 2009).

Hasil analisa yang diperoleh, berdasarkan hasil analisis sidik ragam menunjukkan bahwa perbandingan gelatin dan sukrosa memberikan pengaruh beda nyata pada taraf signifikansi $5 \%$ terhadap kadar gula total marshmallow yang dihasilkan. Pada Tabel 8 menunjukkan kadar gula total paling tinggi terdapat pada perbandingan Gelatin 1 : Sukrosa 12 yaitu sebesar $65.91 \%$, karena semakin tinggi jumlah sukrosa maka kadar gula total marshmallow akan semakin tinggi. Hal ini disebabkan sukrosa mudah terhidrolisis oleh panas pada proses pemasakan, 
sehingga sebagian sukrosa akan terurai menjadi glukosa dan fruktosa atau disebut gula invert (Desrosier, 1988 dalam Alexandro, dkk, 2020). Kadar gula total yang terakumulasi pada data perhitungan tidak hanya berasal dari komponen gula saja, tetapi juga dari bahan dasar lain seperti tepung maizena yang juga mengandung gula (pati) di dalamnya.

\section{Kadar Gula Reduksi}

Menurut istilah umum, gula biasa disebutkan untuk setiap jenis karbohidrat yang digunakan sebagai pemanis. Jenis karbohidrat yang terkandung dalam gula adalah berupa sukrosa dan gula pereduksi. Ada tidaknya sifat pereduksi dari suatu molekul gula ditentukan oleh ada tidaknya gugus hidroksil $(\mathrm{OH})$ bebas yang reaktif. Sukrosa tidak mempunyai gugus $\mathrm{OH}$ bebas yang reaktif karena keduanya sudah saling terikat, karena itu sukrosa bersifat non pereduksi (Winarno, 2004).

Hasil analisa yang diperoleh, Berdasarkan hasil analisis sidik ragam menunjukkan bahwa perbandingan gelatin dan sukrosa memberikan pengaruh beda nyata pada taraf signifikansi $5 \%$ terhadap kadar gula reduksi marshmallow yang dihasilkan. Kadar gula reduksi yang paling tinggi diperoleh pada perbandingan Gelatin 1 : Sukrosa 12 dimana perbandingan ini memiliki jumlah sukrosa tertinggi dengan kadar 23,56\%.

Karbohidrat dalam bahan pangan umumnya menunjukkan beberapa perubahan selama proses pengolahan atau pemasakan. Perubahan yang umum terjadi antara lain dalam hal kelarutan, hidrolisis dan gelatinisasi pati. Pada saat pemanasan, sebagian sukrosa akan terurai menjadi glukosa dan fruktosa. Proses penguraian tersebut dinamakan hidrolisis. Hasil hidrolisis sukrosa yaitu campuran glukosa dan fruktosa disebut gula invert (Poedjiadi, 2005). Hasil yang berbeda dikarenakan sukrosa mengalami hidrolisis, yaitu terpecahnya disakarida menjadi monosakarida berupa glukosa dan fruktosa. Berdasarkan SNI 3547.2:2008 kadar gula reduksi memiliki batas sebesar 25\% sehingga pada hasil yang diperoleh, semua perbandingan telah memenuhi persyaratan.

\section{Tekstur}

Hasil uji tekstur dapat dilihat pada Tabel 2.

Tabel 2. Rerata hasil uji tekstur

\begin{tabular}{cc}
\hline Perlakuan & Fmax N \\
\hline Gelatin 1 : Sukrosa 1 & $1.58817 \mathrm{a}$ \\
Gelatin 1 : Sukrosa 4 & $0.65207 \mathrm{~b}$ \\
Gelatin 1 : Sukrosa 6 & $0.39703 \mathrm{c}$ \\
Gelatin 1 : Sukrosa 8 & $0.2418 \mathrm{~d}$ \\
Gelatin 1 : Sukrosa 12 & $0.17813 \mathrm{~d}$ \\
\hline
\end{tabular}

Keterangan: Rerata yang diikuti huruf yang sama dalam satu kolom menandakan antara perlakuan tidak berbeda nyata pada taraf signifikansi $5 \%$.

Pengujian tekstur marshmallow menggunakan peralatan UTM (Universal Testing Machine) dengan metode tekanan, yaitu, persentase jumlah gaya tekan pada sampel atau produk sehingga mengalami perubahan bentuk ketika dikenakan gaya tekanan tersebut. Pada Tabel 2 menunjukkan adanya beda nyata signifikan pada taraf 5\%, namun pada perbandingan Gelatin 1 : Sukrosa 8 dan Gelatin 1 : Sukrosa 12 tidak ada beda nyata. Hal ini dipengaruhi oleh konsentrasi gelatin yang digunakan. Penggunaan gelatin yang semakin tinggi akan menghasilkan gel yang keras (Fennema, 1985 dalam Sartika 2009). Penggunaan sukrosa yang tinggi turut membuat volume buih marshmallow menjadi lebih besar akan tetapi tekstur yang di dapat tidak begitu kenyal. Dalam sistem pangan, protein dan polisakarida juga dapat berinteraksi dengan komponen lain seperti sukrosa, yang memiliki pengaruh penting pembentukan struktur produk selama langkahlangkah pembuatan.

\section{Hasil Uji Organoleptik}

Uji organoleptik dilakukan oleh 30 orang panelis. Uji organoleptik terhadap marshmallow yang dihasilkan bertujuan untuk mengetahui penilaian panelis terhadap marshmallow dengan perbandingan gelatin dan sukrosa yang dihasilkan melalui pengamatan kesukaan. Hasil uji organoleptik dapat dilihat pada Tabel 3 
Tabel 3. Hasil uji organoleptic marshmallow

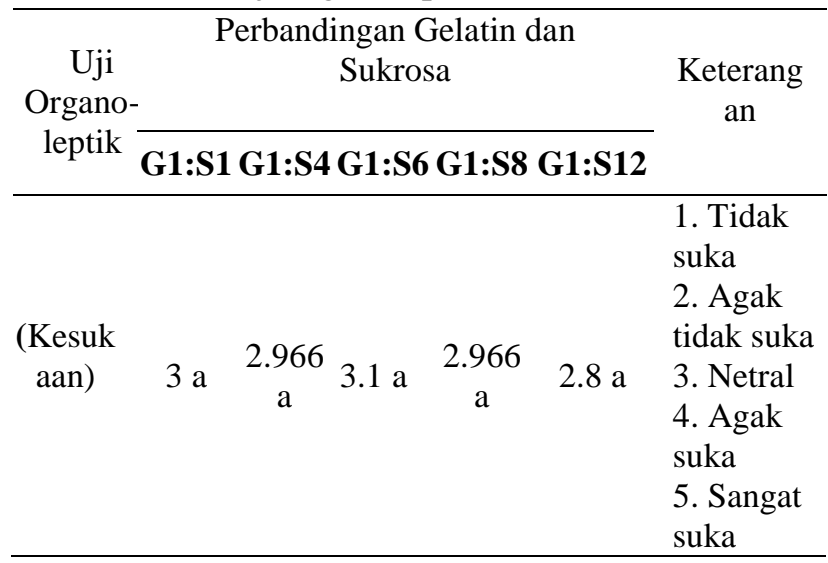

Keterangan: Rerata yang diikuti huruf yang sama dalam satu kolom menandakan antara perlakuan tidak berbeda nyata pada taraf signifikansi $5 \%$.

\section{Kesukaan}

Penerimaan kesukaan merupakan penerimaan panelis secara keseluruhan terhadap beberapa parameter yaitu warna dan tekstur dari marshmallow. Berdasarkan Tabel 3 menunjukkan bahwa antara perbandingan gelatin dan sukrosa memberikan pengaruh tidak beda nyata terhadap nilai kesukaan marshmallow yang dihasilkan.

Pada Tabel 8 memperoleh skor tertinggi pada perbandingan Gelatin 1 : Sukrosa 6 yaitu dengan skor 3.1 dan skor terendah pada perbandingan Gelatin 1 : Sukrosa 8 dengan skor 2.8 .

\section{KESIMPULAN}

Berdasarkan hasil penelitian analisa kimia, fisik, dan organoleptik penelitian yang telah dilakukan terhadap marshmallow dengan perbandingan gelatin dan sukrosa didapatkan kesimpulan bahwa, perbandingan gelatin dan sukrosa memberikan pengaruh beda nyata terhadap sifat fisik, kimia, dan organoleptik dengan parameter uji kimia yaitu : kadar air, kadar abu, kadar sukrosa, kadar gula reduksi. Uji Fisik : tekstur serta uji organoleptik : warna dan tekstur. Namun uji hedonik tidak memberikan pengaruh beda nyata.

Pengaruh gelatin terhadap marshmallow yaitu sebagai agent gelling, agen yang membentuk gel sehingga semakin tinggi gelatin yang ditambahkan maka semakin banyak gel yang terbentuk sehingga membuat tekstur lebih kenyal dan elastis dengan angka yang didapat 1,588 $\mathrm{N}$ dibandingkan marshmallow dengan gelatin yang lebih rendah dengan angka $0,17 \mathrm{~N}$.

Berdasarkan syarat mutu kembang gula lunak, untuk kadar air maksimal yang dianjurkan sebesar 20\%. Pada analisis kimia yang didapat melampaui batas maksimal syarat mutu, namun yang paling mendekati pada perbandingan $28,66 \%$. Syarat mutu kadar abu kembang gula lunak maksimal 3\%. Pada penelitian ini, semua perbandingan telah memenuhi syarat SNI kadar abu. Syarat mutu kadar reduksi kembang gula lunak maksimal $25 \%$ dan semua perbandingan marshmallow telah memenuhi syarat SNI.

Pada uji kesukaan, marshmallow dengan perbandingan gelatin dan sukrosa tidak ada beda nyata, tetapi atas dasar syarat mutu SNI dan hasil organoleptik maka produk terbaik yang dipilih adalah perbandingan Gelatin 1 : Sukrosa 1.

\section{DAFTAR PUSTAKA}

Alexandro, Sidabalok Inawaty, dan Hermalena Leffy. 2020. Karakteristik Mutu Hard Candy dan Aktivitas Antioksidan dengan Penambahan Ekstrak Buah Srikaya (Annona squmosa L). P-ISSN : 25493043 E-ISSN : 2655-3201.

Birch G,G and Parker K,J. 1979. Sucrose and Food Technology. Applied Science Publisher Ltd. London.

Herawati, Heny. 2018. Potensi Hidrokoloid Sebagai Bahan Tambahan Pada Produk Pangan dan Nonpangan bermutu. Jurnal Litbang Pertanian vol 37. No.1 Juni 2018: $17-25$

Jariyah,. Rosida dan Nisa, DC. 2019. Karakteristik Marshmallow dari Perlakuan Proporsi Ciplukan (Physalis peruvania L) dan Jeruk Manis (Citrus Sinensis) serta penambahan gelatin. Jurnal Teknologi Pangan. Vol. 13 No.1 Juni 2019

Lestariani, I., (2008). Pengaruh konsentrasi Sukrosa Dengan Glukosa dan konsentrasi Gelatin Terhadap Karakteristik Soft Candy Mix Fruit Sirsak dan Mangga Kweni, Skripsi Universitas Pasundan, Bandung

Minarni. 1996. Mempelajari Pembuatan dan Penyimpanan Permen Jelly Gelatin dan 
Sari Buah Kweni. [Skripsi]. FATETA IPB. Bogor.

Nadriyanti. 2005. Pengaruh Jumlah Sukrosa dan Jumlah Tepung Biji Asam Jawa Terhadap Karakteristik Soft Candy, Skripsi, Jurusan Teknologi Pangan, Fakultas Teknik, Universitas Pasundan, Bandung.

Nakai, S., and Modler, H.W. 1999. Foods Proteins Processing Application.WileyVHC. London

Poedjiadi, A. 2005. Pendidikan Sains dan Pembangunan Moral Bangsa. Bandung : yayasan Cendrawasih

Santoso, Candra., Surti, Tuti., dan Sumardianto. 2015. Perbedaan Penggunaan Konsentrasi Larutan Asam Sitrat dalam Pembuatan Gelatin Tulang Rawan Ikan Pari Mondol (Himantura gerrardi). Jurnal Pengolahan dan Bioteknologi Hasil Perikanan Volume 4, Nomer 2, Tahun 2015, Halaman 106114.

Sartika, D. 2009. Pengembangan Produk Marshmallow dari Gelatin Kulit Ikan Kakap Merah (Lutjanus sp). [Skripsi]. Fakultas Perikanan dan Ilmu Kelautan. Institut Pertanian Bogor. Bogor.

Tanalo, RAW. 2014. Pengarun Perbedaan Proporsi Sukrosa-Gula Aren Terhadap Sifat Fisikokimia dan Organoleptik Marshmallow. Skripsi. Fakultas Teknologi Pertanian. Universitas Katolik Widya Manggala Surabaya. Surabaya.

Tjokroadikoesoemo, P. S. 1993. HFS dan Industri Ubi Kayu Lainnya. PT. Gramedia Pustaka Utama. Jakarta.

Wahyuni, H. 1998. Mempelajari Pembuatan Hard Candy dari Gula Invert sebagai Alternatif Pengganti Sirup Glukosa [Skripsi]. Fateta.IPB. Bogor.

Winarno FG. 1997. Kimia Pangan dan Gizi. Pt. Gramedia Pustaka Utama. Jakarta.

Winarno FG. 2004. Kimia Pangan dan Gizi. Pt. Gramedia Pustaka Utama. Jakarta.

Zayas, J. F. 1997. Functionality of Protein in Food.Springer. Berlin 